\title{
INTERVENSI PSIKOLOGIS PADA PEMERIKSAAN KDRT (KEKERASAN DALAM RUMAH TANGGA) DALAM PPA (PERLINDUNGAN PEREMPUAN DAN ANAK ) DI POLRESTA MALANG
}

\author{
Josina Judiari \\ Fakultas Psikologi \\ Universitas Islam Negeri (UIN) Maulana Malik Ibrahim Malang \\ Jl. Gajayana 50 Malang Telp. 0341-558916
}

\begin{abstract}
Psychological intervention aimed at analyzing the motif of the informer or victim of the domestic violence and if it is needed, the reported party can be examined his psychological condition. Some test items that selected for the condition are MMPI Test (Mineesole Multiplanic Personality Inventory) that able to display 18 psychological aspects and the mostly highlighted in the initial investigation is the informer honesty. If the score do not fulfill the requirements it is important notes for the investigators to be careful and not accept without ceremony the victim complaints. Color test is personality test that able to reveal the situation target, behavior under pressure or the actual problems. The last, the violence victim can be occurred in the domestic area because the victim give opportunities for the violence occurrence for example too dominant, too sensitive or too relax, do not think her spouse if look at from NSQ (Neurotic Scale Questionaire).
\end{abstract}

Keywords: Psycho test, analysis for domestic case investigation

PSIKOISLAMIKA. Jurnal Psikologi Islam (JPI) copyright @ 2013 Laboratorium Penelitian, Kajian Psikologi Islam dan Penerbitan. Volume 10. Nomor 1, Tahun 2013

\section{PENDAHULUAN}

\section{Kekerasan Dalam Rumah Tangga (KDRT)}

Menurut kamus umum bahasa Indonesia W.J.S. Poerwadarminta, kekerasan berarti sifat atau hal yang keras, kekuatan dan paksaan. Dalam bahasa inggris, yang lebih lazim dipakai orang Indonesia, disebut "violence." Istilah "violence" berasal dari dua kata bahasa Latin : vis yang berarti daya atau kekuatan; dan latus (bentuk perfektum dari kata kerja ferre) yang berarti (telah) membawa. Maka secara harfiah, violence berarti membawa kekuatan, daya, dan paksaan.

Menurut filsuf Thomas Hobbes (1588-1679), manusia dilihat sebagai makhluk yang dikuasai oleh dorongan-dorongan irasionil dan anarkistis serta mekanistis yang saling mengiri dan membenci sehingga menjadi kasar, jahat, buas, pendek pikir. Atas dasar pandangan ini, Hobbes melihat kekerasan sebagai sesuatu yang alamiah bagi manusia Karena itu hanya suatu pemerintahan yang keras dan kuat (memakai kekerasan dan kekuatan) yang dapat mengatasi keadaan tersebut. Berbeda dengan Hobbes, filsuf Jean Jacques Rousseau (1712-1778) beranggapan bahwa manusia secara alamiah adalah ciptaan yang polos, mencintai diri secara spontan, tidak egois dan tidak altruis. Bahwa manusia menjadi seperti binatang yang memiliki sifat agresif/menyerang dan melakukan tindak kekerasan, itu terjadi hanya karena kemajuan dan peradaban. Dengan kata lain, kemajuan dan peradabanlah yang menyebabkan manusia menjadi seperti itu. Menurut seorang lain lagi bernama R. Audi, kekerasan dilukiskan sebagai serangan atau penyalahgunaan fisik terhadap 
seseorang atau binatang; atau serangan penghancuran pengerusakan yang sangat keras, kasar, kejam, dan ganas atas milik atau sesuatu yang sangat potensial dapat menjadi milik seseorang.

Terlepas dari semua pandangan di atas, yang saya maksudkan dengan kekerasan dalam pembicaraan kita ini adalah bukan sekedar kekerasan fisik, tapi juga kekerasan psikis yang merupakan dampak adanya situasi, tindakan, atau sikap dari seseorang mengakibatkan kaum perempuan menderita ketidakadilan.

Jadi, kekerasan dalam rumah tangga dapat disebut semacam penindasan yang artinya "suatu ekses atau penyalahgunaan kekuasaan serta penyalahgunaan kekerasan untuk memaksakan kekuasaannya, atau dalam bahasa kasar si kuat terhadap si lemah dan tak berdaya, perbuatan yang mengena baik pribadi maupun milik orang-orang yang tak berdaya itu".

Dari pelbagai media massa Indonesia akhir-akhir ini, sangat terasa bahwa fakta kekerasan, khususnya kekerasan (seksual) terhadap perempuan, semakin meningkat frekuensinya, baik secara kwantitas maupun secara kwalitas. Dari suatu penelitian yang dibuat oleh Yayasan Konsultasi dan Bantuan Hukum (YKBH) "Yustia" Kupang, terlihat jelas peningkatan frekuensi tadi². Kalau kita mengamati Harian-harian Umum di kota-kotakita saban hari, dapat kita lihat bahwa frekuensi kekerasan terhadap perempuan jauh lebih tinggi dibandingkan dengan kasus-kasus lain seperti pembunuhan dan perselingkuhan.

Tentang kekerasan terhadap perempuan (violence against women) misalnya, dikatakan bahwa hal itu terjadi dimana-mana di dunia ini. Di india misalnya setiap hari rata-rata 5 perempuan dibakar mati sehubungan dengan mas kawin. Di PNG, sekitar 67\% perempuan menderita kekerasan domestik (dianiaya suami). Di Amerika Serikat, setiap 8 detik seorang perempuan mendapat perlakuan kasar secara fisik, setiap 18 menit seorang perempuan dipukul, setiap 6 menit seorang perempuan diperkosa.

\section{METODE INTERVENSI}

Intervensi merupakan studi kasus ( $\mathrm{N}=1)$ dengan menggunakan beberapa tes psikologi yaitu MMPI, Colour Tes dan NSG. Beberapa tes ini telah dipilih sehingga relevan untuk mengetahui kondisi psikologi pelapor (korban) KDRT. Beberapa tes ini telah memiliki validitas dan reabilitas yang sudah digunakan secara hati-hati dan confidential di dunia psikologi baik di luar negeri maupun di Indonesia.

Gabungan tes 3 test ini telah digunakan oleh peneliti untuk kasus KDRT di PPA (Perlindungan Perempuan \& Anak) yang didalamnya termasuk kasuskasus lain seperti pelecehan seksual, kekerasan psikis, penelantaran dalam rumah tangga, dan lain-lain. Dan hasilnya ketiga tes ini mempunyai analisa yang sama dan saling terkait sehingga dapat dijadikan cross-check, baik bagi diri psikolog maupun crosscheck dengan pihak penyidik. Walaupun test MMPI saja sudah cukup mengungkap, karena pemeriksaan ini dilakukan di POLRES, maka informasi-informasi penting yang diperlukan sebaiknya lengkap dan akurat.

Selain tes cara observasi itu dilaksanakan dengan penyelidikan.

1. Tes MMPI

2. Tes Warna

3. Tes NSG

Melalui cara ini diharapkan dapat memperoleh gambaran tentang kasus yang dihadapi penyidik dengan psikolog sehingga masing pihak dapat terbantu untuk menyimpulkan kebenaran. Apalagi bila suatu kasus ini diteruskan ke pengadilan, dan laporan psikologi ini bila masuk dalam ranah hukum, maka psikolog akan dilibatkan sebagai saksi ahli.

\section{Subyek}

Subyek pada intervensi ini adalah seorang wanita berumur 41 tahun yang selalu cemas karena ulah suaminya.

\section{Metode Pengumpulan Data}

Data dalam pemberian intervensi psikologi pada korban KDRT ini adalah menggunakan 3 test psikologi yang memakan waktu lebih kurang 3 jam sambil dilakukan observasi. Data lengkap sudah ada dalam laporan di POLRES. Psikolog tidak memerlukan wawancara, tetapi khusus psikolog saja karena alasan off the record dari korban. Dengan demikian laporan hasil dari pskilog soal itu tidak terpengaruh apapun. Setelah hasil tes selesai dikirim ke POLRES. Baru bila perlu dimulai mengurai lewat BAP (Berita Acara Pemeriksaan).

\section{Prosedur Pemeriksaan}

1. Mengklarifikasikan masalah

2. Latar Belakang

Subjek melapor ke KDRT karena menderita yang disebabkan oleh ulah suaminya.

Seperti pada kenyataan KDRT itu ada 2 macam:

a. Kekerasan fisik (ini bisa ditimbulkan lewat visum reperlium di RSU) 
b. Kekerasan psikis, kekerasan ini tidak kasat mata, tetapi polisi mengarahkan pada psikolog melalui surat pengantar untuk periksa konsultasi psikologi korban.

3. Pemeriksaan Psikologi

a. MMPI

Untuk mengetahui dimensi-dimensi kepribadian tertentu pada diri seseorang telah dikembangkan berbagai tes psikologi; dan salah satu diantaranya adalah MMPI (Minesota Multiphasic Personality Inventory). MMPI dapat membantu klinikus mendapatkan gambaran yang akurat tentang berbagai dimensi kepribadian sesorang pasien. MMPI dapat berfungsi sebagai penunjang/ pelengkap diagnosis klinik.

Sebelum memberikan terapi psikiatrik, seseorang klinikus hendaknya terlebih dahulu menegakkan diagnosis multiaksial pada pasiennya, yang meliputi:

Aksis 1 = sindroma klinik

Aksis 2 = ciri kepribadian

Aksis 3 = kelainan/penyakit fisik

Aksis 4 = Stresor psikososial

Aksis 5 = kemampuan adaptasi (dalam tahun terakhir)

Kedudukan MMPI pada diagnosis klinis aksis 2 (kepribadian) lebih bersifat kualitatif. Sama halnya dengan klinikus ahli penyakit dalam, sudah dapat mendiagnosis pasien apakah penderita anemia atau tidak cukup dengan pemeriksaan fisik (physical examination). Namun untuk mengetahui beberapa derajat anemianya (kadar $\mathrm{Hb}$ dalam darah) diperlukan pemeriksaan laboratorium.

\section{MMPI}

MMPI adalah salah satu bentuk tes psikologik yang disusun sedemikian rupa sehingga merupakan instrumen yang secara akurat dapat memberikan gambaran dari dimensi-dimensi-dimensi kepribadian tertentu. Test MMPI terdiri dari 566 pernyataan (item). Dari semua item ini disusun apa yang dinamakan 4 skala validitas dan 10 skala klinis. Hasil skoring dari masing-masing skala digambarkan dalam bentuk grafik MMPI. Score antara 30 - 70 normal, sedangkan skore di atas 70 menunjukkan adanya kelainan psikopatologik. Khusus untuk Indonesia telah disusun T-Skore dalam bentuk tabel untuk pria dan wanita yang telah diujikan validitasnya. (Rudy Salam, 1984).

\section{Kepribadian}

Kusumanto (1963) memberikan batasan kepribadian adalah : “ segala corak kebiasaan manusia yang terhimpun dalam dirinya, yang digunakan untuk bereaksi serta menyesuaikan diri terhadap segala rangsangan, baik timbul dari lingkungannya (dunia luar) maupun yang datang dari dirinya sendiri (dunia dalam) sehingga corak dan kebiasaan itu merupakan satu kesatuan fungsional yang khas untuk individu itu".

Dikatakan kepribadian seseorang sehat apabila ia mampu untuk memperoleh penyelesaian-penyelesaian secara efektif, efisien dan positif dalam situasi hidup yang berubah-berubah, serta mampu mencernakan secara luas pengetahuan yang diperolehnya dalam pendidikan baik formal maupun non formal, serta pengalaman dalam kehidupan di masyarakat.

Menurut PPDGJ-II yang dimaksudkan dengan kepribadian adalah pola dari persepsi, cara mengadakan hubungan dan cara berpikir yang menetap tentang lingkungan dan diri sendiri dan dinyatakan secara luas di dalam konteks kehidupan sosial dan hubungan pribadi seseorang. Dikatakan suatu kepribadian terganggu (tidak sehat) apabila kepribadian seseorang tidak fleksibel dan sulit untuk menyesuaikan diri dengan lingkungan hidupnya, sehingga hendaknya dalam hubungan / fungsi sosial atau pekerjaan atau menimbulkan penderitaan subyektif bagi dirinya.

Secara umum adanya gangguan kepribadian pada diri seseorang dapat dilihat apabila terdapat:

- Perasaan tidak puas dengan dampak perilakunya terhadap orang lain

- Ketidakmampuan/hendaknya untuk berfungsi secara wajar (adekwat) dan efektif di rumah, sekolah, pekerjaan dan lingkungan sosial.

- Penderitaan subyektif berupa kecemasan atau depresi.

Pada hasil pemeriksaan MMPI dapat dilihat gambaran atau profil dari dimensi-dimensi kepribadian yang diuraikan dalam 4 skala validitas dan 10 skala klinis yang dapat ditafsirkan secara terinci. Skala yang lazim digunakan dalam klinis dan merupakan basisi dari analisis MMPI adalah sebagai berikut:

Skala Validitas:

- Skore yang tidak diisi Tanda (?)

- Skore kebohongan Tanda (L)

- Skala keliru isiTanda (F)

- Skala koreksi Tanda (K) 
Skala Klinik:

1. Skala Hipokondriasis

Tanda 1-Hs

2. Skala Depresi

3. Skala Histeri

4. Skala Deviasi Psikopatik

Tanda 2-D

Tanda 3-Hy

Tanda 4-Pd

5. Skala Minat (pria/wanita)

Tanda 5-Mf

Tanda 6-Pa

Tanda 7-Pt

Tanda 8-Sc

Tanda 9- $\mathrm{Ha}$

Tanda 0-Si

10. Skala Introversisos

Skala validitas dimaksudkan sebagai alat pengontrol. Bila pada skala ini terdapat hasil yang terlampau tinggi, maka hal ini merupakan indikasi skala lain/skala klinik, atau kurang dapat dipercaya kebenarannya.

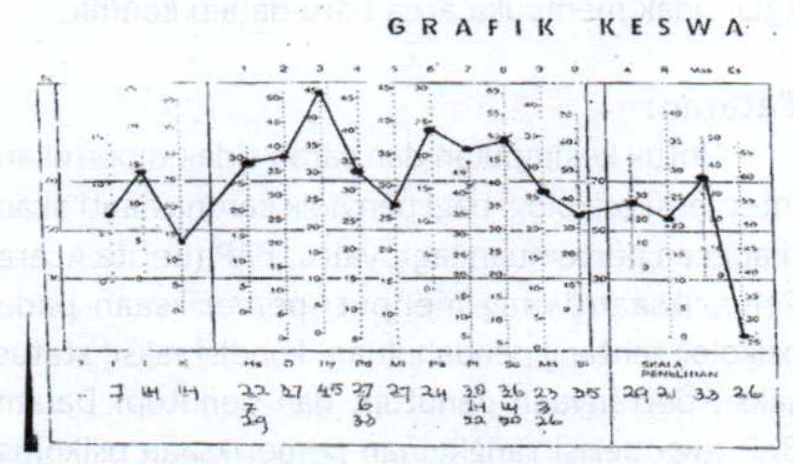

Dari Hasil Tes MMPI

Diasumsikan: 1) bahwa keterangan subyek dapat dipercaya

2) Terdapat keluhan-keluhan somatik

3) Sedikit depresi/ agak tertekan

4) Mudah terpengaruh oleh sugesti dari luar dan mudah bereaksi emosi

5) Selalu curiga, egosentrik, merasa bahwa masyarakat kurang membantu

6) Cemas dan kurang percaya diri

7) Agak menyendiri dan kurang suka bergaul

\section{Colour Tes Max Luscher}

Colour tes sering disebut dalam kelompok psikologi fungsional. Yang dimaksud dengan psikologi fungsional adalah teori yang berhubungan dengan pilihan individu terhadap warna secara psikologis. Dalam tes warna Luscher, "susunan" warna adalah konstan, yaitu "arti obyektif" --- warna tidak berubah dan tetap sama bagi siapa saja. Misalnya, biru hitam berarti "tenang dan damai" terlepas dari persoalan seseorang apakah seseorang menyenanginya atau tidak. Sebaliknya, "fungsi" adalah "sikap" subyektif terhadap warna" dan inilah yang berbeda pada setiap individu, dan pengertian tes seperti yang dimaksudkan dalam buku ini berdasarkan "fungsi" ini. Seseorang mungkin menyenangi salah satu warna yang oleh orang lain mungkin dinilai sebagai warna yang membosankan, sedangkan orang yang ketiga mungkin tidak menyenanginya atau tidak merasa bosan terhadap warna yang sama, sementara orang yang tidak mempunyai dampak apapun terhadap warna tersebut.

Dalam tes, orang yang sedang dites atau sedang mentes dirinya sendiri, memilih warna dari urutan yang paling disenanginya sampai yang paling tidak disenanginya. Warna yang paling tidak disenanginya yang ditempatkan pada posisi kedelapan adalah yang dia menaruh antipati paling besar (atau simpati yang paling minim). Dengan memperhatikan dimana letak sebuah warna di jajaran warna, kita dapat menentukan "fungsi" apa yang ditandai oleh warna itu, karena sikap subyektif seseorang terhadap warna bervariasi dari yang paling disenangi sampai yang paling tidak disenangi.

Pada bagian pertama jajaran warna terhadap warna yang paling disenangi, kemudian menyusul warna yang disenangi tapi kurang mendapat perhatian, kemudian sampai warna "netral" dan terakhir pada warna yang paling tidak disenangi atau bahkan ditolak. Lambang yang digunakan untuk menandai bagian-bagian ini adalah sebagai berikut:

Sangat disenangi (simpati) : + (tanda tambah)

Kurang disenangi : $x$ (tanda kali)

Netral : $=$ (tanda sama dengan)

Antipati (atau ditolak) : - (tanda kurang)

Yang sering menggunakan Test Luscher antara lain: ahli penyakit jiwa, dokter medis, ahli pendidikan, dan ahli kriminologi. Mereka umumnya menginginkan tabel ini guna dipraktekkan menurut metode masingmasing. Data-data mungkin diperlukan bagi umur dan jenis kelamin yang berbeda, kondisi sosiologis yang berbeda dan untuk diagnosa serta mungkin untuk keperluan medis.

\section{Analisis}

Subyek mengharapkan ada pengertian dan simpati, ingin melindungi diri dari konflik.

Ada rasa tegang yang melelahkan. Juga butuh penghargaan dan pengertian dari orang terdekatnya. Kecewa karena situasi tidak seperti yang diharapkan, bahkan merasa terperangkap dalam situasi yang tidak menyenangkan. Subyek sudah berusaha menghindari konflik. 


\section{6}

\section{N S Q (Neurotic Scale Question)}

N S Q merupakan alat tes yang canggih, standard dan mudah digunakan untuk mengukur kecenderungan Neurotic. NSQ dikembangkan oleh Sheier dan Cattell (1961). NSQ disusun berdasarkan empat komponen utama, yaitu faktor I, F, E, dan An. Pada komponen ke empat dibagi menjadi tiga faktor yaitu O, Q, dan C ( Sheier dan Cattell, 1961 ).

Faktor I, meliputi : "over Protection", "Tender Minded", "Cultured", dan "Protection Emotional Sensitivity" (lawan dari "Tough Mindedness").

Faktor F meliputi : “depressiveness", "inhibited", ‘ "sober","seriousness" (lawan dari "happy go lucky cheerfulness").

Faktor Emeliputi : "submissiveness", "sugestibilit", "dependency" (lawan "dominance").

Faktor ke empat an (anxiety) yang terdiri dari komponen factor 0, meliputi "worry", "guilt proneness" (lawan dari "assured self confidence". Faktor Q meliputi : “ergic tention” (lawan dari “calm relaxation"). Faktor ( meliputi "ego weakness" atau "emotional Immaturity dan "insability" (lawan dari “ego strength").

NSQ terdiri dari 40 item, yang setiap itemnya mempunyai tiga alternative jawaban A, B, dan C. Pemberian skornya bergerak dari 0,1 , dan 2 . Skor tertinggi adalah 80 .

Validitas dan reliabilitas NSQ, menurut Sheier dan Cattell dari beberapa penelitian yang dilakukan telah didapatkan angka validitas faktor $\mathrm{I}=0,74$, faktor $F=0,76$, faktor $E=0,69$, dan faktor $A n$ $=0,84$. Untuk mendapatkan relibilitas NSQ telah dilakukan penelitian dengan menggunakan teknik "split half" dan "formula Spearman Brown", dengan hasil koefisien reliabilitas masing-masing faktor adalah sebagai berikut: Faktor $\mathrm{I}=0,55$, faktor $\mathrm{F}$ $=0,57$, faktor $E=0,47$, dan faktor $A n=0,70$.

\section{Hasil test N S Q}

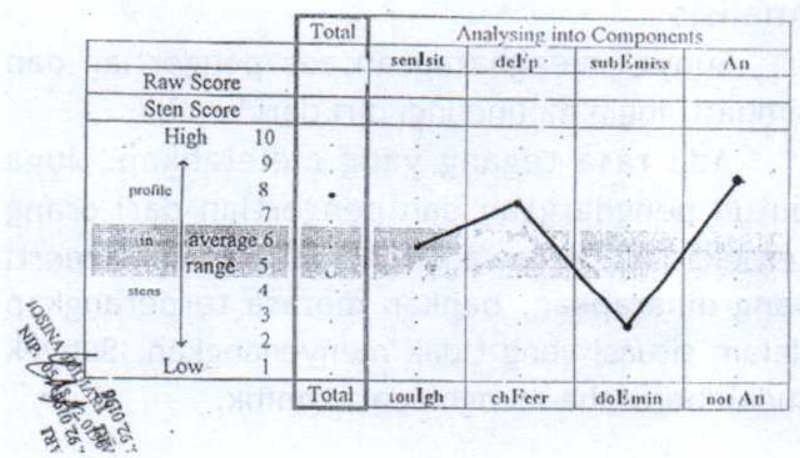

Hasil Tes Neurotic Scale Questionair diperoleh sebagai berikut:

Secara umum memang subyek mengalami masalah, terutama adalah kecemasan. Juga sedikit depresi. Dalam urusan rumah tangga subyek punya peran penuh (domain).

\section{KESIMPULAN}

- Subyek mengalami depresi dan juga kecemasan karena kekerasan psikis.

- Keterangan subyek dapat dipercaya

- Subyek memang memerlukan bantuan terhadap masalah yang dihadapi

\section{SARAN}

Subyek diminta untuk tidak terlalu dominan dalam pembacaraan, penghasilan dan sebagainya agar tidak membuka area baru dalam konflik.

\section{Catatan:}

Untuk kesimpulan dan saran tidak diperlukan intervensi psikologi bagi penyidik karena nanti akan diadakan pertemuan lagi, yaitu, BAP (Berita Acara Pemeriksaan) yang meliputi pemeriksaan pada psikolog tentang pendahuluan, kondisi saksi, status saksi, pertanyaan penutup, dan penutup. Dalam BAP juga berisi rangkuman pemeriksaan psikolog mengenai kesimpulan dan hasil. Bila berlanjut di pengadilan psikolog akan diminta menjadi saksi ahli juga menerangkan hasil test psikologi itu.

\section{DAFTAR PUSTAKA}

Bell R 1982, Marriage and Family Ontario Interaction, The Dorsy Press

Benyamin Y BriaPr Mgr Dr 2003 Kekerasan terhadap Perempuan dan bagaimana menyikapinya. Yayasan Pustaka Nusantara Yogyakarta.

Chaplin CP 1993 Kamus lengkap Psikologi Terjemahan

E Koeswara PT Eresco Bandung

Dahlstrron W Grant and Welsh, Georche Schlager 1960 An MMPI Handbook A Guide to use in Clinical Practice and Research The University of MinnesotaPress Minneapolis

John H G Grist MD, James W Jeffreson M D 1988

Back Depression Inventory. American Psychiatrst

Press Inc Press Washington DC

Max Luscher Dr 1999 The Luscher Color Test. Avenue of the American NY 10020

Endang Poerwanti Dra M.Pd 1998, Dimensi-dimensi Riset IImiah UMM Press Malang 
Howard S Friedman, Mirian W Schustack 2006 Kepribadian dan Teori Klasik dan Riset Modern, Erlangga Jakarta

Jane C Duckworth PhD, Raymond Cattel PhD 1961 Handbook for the Neurotic Scale Questionnaire “ The NSQ “ by Institute For Personality USA J Nuttin en Breetn 1969 Handleiding biy de Persoonlijkheidsenventaris MMPI Published by The Psychological Corporation New York

Rudy Salam Adaptasi MMPI pada subyek Normal Makalah HIMPSI tidak diterbitkan
Rusdi Maslim 2003 Diagnosis Gangguan Jiwa, PPDGL III PT Nuh Jaya Jakarta

Robert, Priest 1994 Stress dan Depresi Dakara Press Semarang

Salomon P dkk 1992 Handbook Psychiatry Japan Lange. Medical Publication Marusen Company Limited

Suhartono 1999 Metode Penelitian Sosial, Rosa Karya Bandung

Suryabrata 2000 Metode Penelitian Raja Grafindo Jakarta 